\title{
Ethnobotany, diverse food uses, claimed health benefits and implications on conservation of barley landraces in North Eastern Ethiopia highlands
}

\author{
Hailemichael Shewayrga ${ }^{1 *}$ and Peter A Sopade ${ }^{2,3}$
}

\begin{abstract}
Background: Barley is the number one food crop in the highland parts of North Eastern Ethiopia produced by subsistence farmers grown as landraces. Information on the ethnobotany, food utilization and maintenance of barley landraces is valuable to design and plan germplasm conservation strategies as well as to improve food utilization of barley.
\end{abstract}

Methods: A study, involving field visits and household interviews, was conducted in three administrative zones. Eleven districts from the three zones, five kebeles in each district and five households from each kebele were visited to gather information on the ethnobotany, the utilization of barley and how barley end-uses influence the maintenance of landrace diversity.

Results: According to farmers, barley is the "king of crops" and it is put for diverse uses with more than 20 types of barley dishes and beverages reportedly prepared in the study area. The products are prepared from either boiled/roasted whole grain, raw- and roasted-milled grain, or cracked grain as main, side, ceremonial, and recuperating dishes. The various barley traditional foods have perceived qualities and health benefits by the farmers. Fifteen diverse barley landraces were reported by farmers, and the ethnobotany of the landraces reflects key quantitative and qualitative traits. Some landraces that are preferred for their culinary qualities are being marginalized due to moisture shortage and soil degradation.

Conclusions: Farmers' preference of different landraces for various end-use qualities is one of the important factors that affect the decision process of landraces maintenance, which in turn affect genetic diversity. Further studies on improving maintenance of landraces, developing suitable varieties and improving the food utilization of barley including processing techniques could contribute to food security of the area.

\section{Background}

In developed countries, barley is primarily used for animal feed, malting and brewing with little designated for food. However, in Ethiopia and many developing countries, barley is produced mainly as a food crop, and it is the fifth most important cereal crop in Ethiopia after tef, maize, sorghum and wheat [1]. The country is recognized as the secondary centre of diversity for barley [2], and the Ethiopian barley germplasm has been

\footnotetext{
*Correspondence: haileb_02@yahoo.com

${ }^{1}$ Sirinka Agricultural Research Center, P.O.Box 74, Woldia, Ethiopia
}

Full list of author information is available at the end of the article important worldwide as a source of useful genes for traits such as disease resistance $[3,4]$. The crop is produced by subsistence farmers mostly grown as landraces with little or no application of fertilizers, pesticides and herbicides [5]. Landraces are defined as traditional varieties developed through natural and human selections, which are named and maintained by traditional farmers to meet their social, economic, cultural, and ecological needs [6]. Barley is cultivated from 1400 to over $4000 \mathrm{~m}$ above sea level, and its importance increases in droughtprone areas and at higher elevations (above $2800 \mathrm{~m}$ ) where poor soil fertility, frost, water logging, and soil 
acidity and degradation are the major yield limiting factors $[5,7]$. The major barley producing regions in Ethiopia are Oromiya, Amhara and Tigray Regional States, which account for about $87 \%$ of the national barley production [1]. Therefore, barley holds an important position in the food security of Ethiopia.

Access to a range of crop genetic variability is critical to the success of breeding programs, and consequently to food security and human nutrition $[8,9]$. Landraces are considered more locally adapted and genetically variable than modern cultivars $[6,10]$. They contribute to agricultural production around the world, particularly for the rural poor in marginal environments as source of seed for next season planting $[5,10]$. Farmers make crop maintenance decisions based on combinations of factors including adaptability, yield, socio-cultural values and food traditions as well as nutritional values. These decisions affect the genetic diversity of crop populations $[7,11,12]$. Farmers' maintenance approaches have allowed the continual evolution of landraces diversity in their area of adaptation. This diversity has been the key to food security for generations and an invaluable resource for crop improvement activities around the world.

Knowledge of the utilization and traditional food processing techniques as well as types of germplasm maintained by farmers are prerequisite for investigating ways to improve the germplasm maintenance of a food crop.
The information is also important for understanding nutritional qualities as well as processing techniques. In Ethiopia, Tsegaye and Berg [13] investigated the utilization of durum wheat landraces in East Shewa. They identified 14 dishes and two drinks derived from landraces. This richness in food tradition was associated with a high level of on-farm landrace diversity. With regards to barley, there have been efforts, though limited, on documentation of its utilization and ethno-botany for some parts (e.g. Central) of Ethiopia [5,14-16]. We conducted a study on barley utilization in North Eastern Ethiopia with the main objectives to (1) document the importance, ethnobotany and types of barley landraces grown; (2) investigate and gather information on the utilization of barley and its importance in the diets of the people, and the dishes prepared; (3) examine how barley end-uses influence the maintenance of its landraces.

\section{Research Methods}

\section{Description of the study area}

The study area is located in the highlands of North Eastern Ethiopia covering three administrative zones (provinces) of the Amhara Regional State: Wag Hemra, North Wello (N.Wello) and South Wello (S.Wello) (Figure 1). Eleven barley growing woredas (districts) were selected from the three zones: Sekota and Dehana from Wag Hemra; Gidan, Gubalafto, Meket and Wadla from

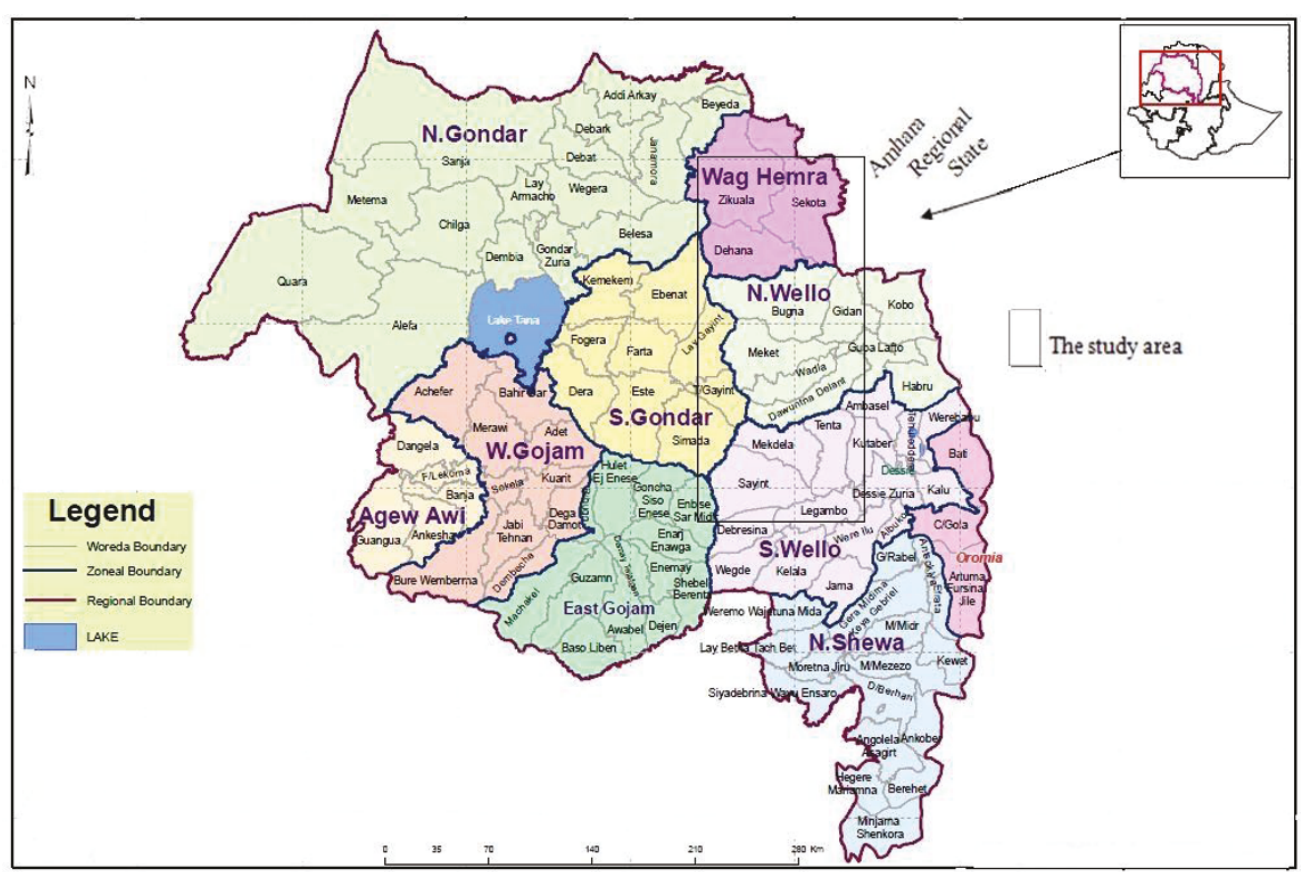

Figure $1 \mathrm{Map}$ of Ethiopia and the study area. (source http://www.ocha-eth.org/Maps/downloadables/AMHARA.pdf accessed on 30 January 2010). 
N.Wello; and Kutaber, Dessie zuria, Tenta, Legambo and Wereilu from S.Wello. Woredas are small administrative units within a zone, and a woreda is subdivided into smaller administrative units called kebeles (peasant associations). The woredas are divided into highland (dega), intermediate (woyna dega) and low land (kola) ecologies based on altitude. The study areas covered only highland parts of each woreda which fall within $10^{\circ} 50^{\prime} 60 \mathrm{~N}$ $12^{\circ} 37^{\prime} 50 \mathrm{~N}$ latitude and $39^{\circ} 2^{\prime} 5 \mathrm{E}-39^{\circ} 10^{\prime} 60 \mathrm{E}$ longitude ranges with Sekota town in Wag Hemra and Akesta town in S. Wello as the most northerly and southerly places with altitudes ranging from $2000-3400 \mathrm{~m}$.

North Eastern Ethiopia is generally characterized by rugged mountains, hills and valley bottoms and all the barley growing places of the woredas were accessible by gravel roads. Small land holding $(0.5 \sim 1 \mathrm{ha})$ is one of the prominent features of the mixed (crop and livestock) subsistence farming system, and even steep slopes are put into crop production (e.g. Figure 2). Land degradation and low soil fertility are major problems with the situation in Wag Hemra being the most affected. Previous studies indicated the need for the application of fertilizers to increase yield (Sirinka Agricultural Research Center, unpublished report). The rainfall distribution is bimodal in Kutaber, Dessie zuria, Tenta, Legambo, parts of Wereilu, Guba lafto, Meket, Wadla, and Gidan. But in Sekota and Dehana, parts of Gidan, Meket, Wadla and Wereilu, the rainfall is uni-modal (Table 1). At times, the rainfall can be erratic in distribution and inadequate in amount, leading to crop failures.

\section{Sampling Procedures}

Kebeles and peasant households constituted the sampling frame. From each woreda, five kebeles, and from each kebele, five households were randomly selected to

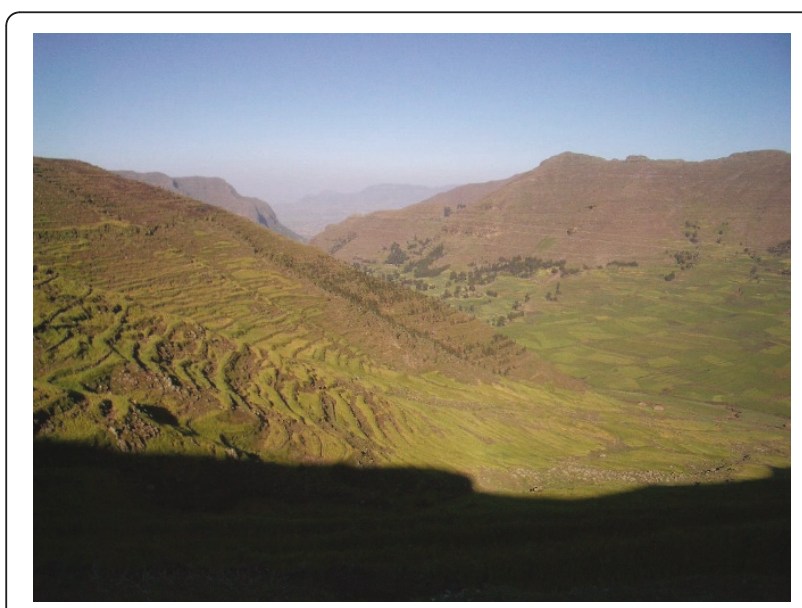

Figure 2 Showing barley fields in a degraded and steep slope area around dilb area in N.Wello provide a sample total of 275 households. The highlands are some of the densely populated areas in the country. In terms of religion, farmers in S.Wello are predominantly Muslims and those in N.Wello and Wag Hemra zones are predominantly Christians. Ethnicity wise, farmers in N.Wello and S. Wello are Amhara, and those in Wag Hemra include Amhara and Agew (Table 2). Amhara is one of the largest ethnic groups accounting more than 25\% of Ethiopian population [17,18]. Except Sekota, more than $99 \%$ of the dwellers in the study districts are Amharic speaking people.

We visited individual farmers' places (home or farm) to gather the information. Using an open ended questionnaire, interviews and discussions were conducted involving the men and women at times to get information on practices that require specific knowledge and skills of either member of the household. Women are traditionally responsible for preparing foods, and therefore, more knowledgeable about food preparatory techniques and cooking qualities. The farmers were asked to describe the cropping practices, the types, names, characters and quality attributes of landraces grown, the types of barley foods and beverage products and their preparations. The information collected was more descriptive of the practices rather than quantitative measurements. In some cases, the discussions were turned into group discussions with the neighbours turning up for curiosity. Their involvements in the discussions were entertained, and consensus opinions were taken. Development agents, subject matter specialists of agricultural office of the districts and administrative staffs of kebeles cooperated in contacting farmers for the discussion. Information from all the study areas was summarized, and where differences were observed from areas to areas, such cases were indicated. Whenever possible, secondary data were surveyed from published sources.

\section{Results}

Importance of barley

According to the farmers, barley is the king of crops ("gebs ye ehil nigus") and it is preferred to other crops. Some of the reasons for this as stated by the farmers are summarized (Table 3). It is the number one crop both in terms of acreage and production in the surveyed areas produced during both meher (main rain) and belg (small rain) seasons. In the higher altitude areas $(>3000 \mathrm{~m})$, barley is the only crop with linseed and potato cultivated in few areas and on very small plots. Wheat, faba bean, field pea, linseed, lentil, maize, potato and tef are important components of the cropping system in some areas, particularly in areas with altitudes from $2000-2400 \mathrm{~m}$. For example, farmers in Dessie Zuria and Kutaber grow maize, pulses and tef during the meher season on plots that are relatively well drained and not affected by frost, 
Table 1 Mean monthly rainfall for selected stations in the study districts

\begin{tabular}{|c|c|c|c|c|c|c|c|c|c|c|c|c|c|c|c|}
\hline \multirow[t]{2}{*}{ Zone } & \multirow[t]{2}{*}{ District } & \multirow[t]{2}{*}{ Station } & \multicolumn{12}{|c|}{ Months } & \multirow[t]{2}{*}{ Total } \\
\hline & & & Jan & Feb. & Mar. & Apr. & May & Jun & Jul. & Aug. & Sep. & Oct. & Nov. & Dec. & \\
\hline Wag Hemra & Sekota & Sekota & - & - & - & - & - & - & - & - & - & - & - & - & 575.4 \\
\hline N.Wello & Meket & Estaysh (6) & 7.0 & 10.3 & 79.4 & 82.0 & 16.8 & 20.2 & 332.7 & 271.6 & 46.6 & 23.1 & 8.3 & 7.8 & 905.7 \\
\hline N.Wello & Gidan & Kulmesk (10) & 9.4 & 0.0 & 0.0 & 16.9 & 0.2 & 0.0 & 286.0 & 285.3 & 109.7 & 10.3 & 29.1 & 25.6 & 772.5 \\
\hline S.Wello & Dessie zuria & Boru Meda (13) & 33.2 & 38.8 & 58.6 & 102.9 & 53.0 & 34.0 & 386.9 & 274.9 & 124.7 & 66.6 & 16.7 & 11.2 & 1203.5 \\
\hline S.Wello & Dessie & Dessie (9) & 39.4 & 41.3 & 80.3 & 102.8 & 74.4 & 33.1 & 326.2 & 340.7 & 155.0 & 73.1 & 40.6 & 24.4 & 1331.2 \\
\hline S.Wello & Kutaber & Kutaber (13) & 13.9 & 16.4 & 45.5 & 62.3 & 67.3 & 49.5 & 337.6 & 323.0 & 151.3 & 37.98 & 16.75 & 7.8 & 1129.2 \\
\hline S.Wello & Woreilu & Woreilu (7) & 16.2 & 26.7 & 46.4 & 42.6 & 37.5 & 33.8 & 287.8 & 266.0 & 54.0 & 11.3 & 10.6 & 5.3 & 838.2 \\
\hline
\end{tabular}

Source: Sirinka Agricultural Research Center [unpublished data]. *number $\mathrm{s}$ in parenthesis next to station names indicate the number of years from which the average was calculated for years 1989 to 2000 for N.\&S.Wello. The value for Sekota is long-term average from 1971 to 2004 [source: 50 ]

and grow barley during belg. Similarly, in N.Wello and Wag Hemra, barley is grown along with wheat, tef and various pulses. Barley is less important in areas below $2000 \mathrm{~m}$. Over all, barley ranks $3^{\text {rd }}$ or $4^{\text {th }}$ in terms of area and production in the three zones (Table 4).

Farmers store barley grains and seeds in a well-prepared underground pit to protect from weevils and molds damage as well as other physiological changes that cause loss of viability. Produces from different landraces are stored separately unless they are grown in mixtures. From interviews, barley grains can be stored for 5-25 years depending on the storage conditions, with dry and cold places being ideal for long storage. However, nowadays farmers hardly produce any surplus that can be stored for more than a year. Very small amount of barley grain is sold to generate cash.

Meher production is the predominant system in $N$. Wello and Wag Hemra while belg is the predominant system in S.Wello. The meher season is through May to December (with July and August being the main rainfall

Table 2 Area, altitude and population demography of the study districts

\begin{tabular}{|c|c|c|c|c|c|c|}
\hline District & $\begin{array}{l}\text { Area (sq. } \\
\mathrm{km})\end{array}$ & $\begin{array}{l}\text { Altitude } \\
\text { (masl) }^{* *}\end{array}$ & Population & Ethnicity & $\begin{array}{l}\text { Main Language } \\
\text { spoken }\end{array}$ & Religion* \\
\hline \multicolumn{7}{|l|}{$\begin{array}{l}\text { Wag } \\
\text { Hemra }\end{array}$} \\
\hline Sekota & $1,722.43$ & $\begin{array}{l}1100 \text { to } \geq \\
3810\end{array}$ & 112,396 & $\begin{array}{l}\text { Agaw/Kamyr (74.24\%) Amhara (22.57\%) } \\
\text { Tigrayan (3.06\%) }\end{array}$ & Amharic Kamyr & Christian (99.34\%) \\
\hline Dehana & $1,643.07$ & - & 109,725 & Amhara (98.74\%) Agaw/Kamyr (1.11\%) & Amharic & Christian (99.8\%) \\
\hline \multicolumn{7}{|l|}{ N. Wello } \\
\hline Gidan & $1,089.80$ & $\begin{array}{l}1300 \text { to } \geq \\
4100\end{array}$ & 158,428 & Amhara (99.96\%) & Amharic & Christian (99.63\%) \\
\hline Gubalafto & 900.49 & $\begin{array}{l}1300 \text { to } \geq \\
3900\end{array}$ & 139,825 & Amhara (99.92\%) & Amharic & $\begin{array}{l}\text { Christian (88.55\%) Muslim } \\
(11.42 \%)\end{array}$ \\
\hline Meket & $1,909.25$ & $\begin{array}{l}1200 \text { to } \geq \\
3000\end{array}$ & 226,644 & Amhara (99.95\%) & Amharic & Christian (94.69\%) \\
\hline Wadla & 855.29 & $\begin{array}{l}700 \text { to } \geq \\
3200\end{array}$ & 128,170 & Amhara (99.94\%) & Amharic & Christian (96.21\%) \\
\hline \multicolumn{7}{|l|}{ S. Wello } \\
\hline Kutaber & 719.92 & $\begin{array}{l}800 \text { to } \geq \\
3200\end{array}$ & 95,410 & Amhara (99.86\%) & Amharic & $\begin{array}{l}\text { Muslim (88.65\%) Christian } \\
(10.78 \%)\end{array}$ \\
\hline $\begin{array}{l}\text { Dessie } \\
\text { zuria }\end{array}$ & 937.32 & $\begin{array}{l}1800 \text { to } \geq \\
3500\end{array}$ & 157,679 & Amhara (99.93\%) & Amharic & $\begin{array}{l}\text { Muslim (97.72\%) Christian } \\
(2.21 \%)\end{array}$ \\
\hline Woreilu & 740.96 & $\begin{array}{l}1700 \text { to } \geq \\
3200\end{array}$ & 109,244 & Amhara (99.91\%) & Amharic & $\begin{array}{l}\text { Muslim (80.04\%) Christian } \\
(19.83 \%)\end{array}$ \\
\hline Legambo & $1,017.35$ & $\begin{array}{l}1500 \text { to } \geq \\
3700\end{array}$ & 165,026 & Amhara (99.9\%) & Amharic & $\begin{array}{l}\text { Muslim }(92.99 \%) \text { Christian } \\
(6.82 \%)\end{array}$ \\
\hline Tenta & $1,316.34$ & $\begin{array}{l}600 \text { to } \geq \\
3700\end{array}$ & 166,239 & Amhara (99.93\%) & Amharic & $\begin{array}{l}\text { Muslim (77.92\%) Christian } \\
(21.95 \%)\end{array}$ \\
\hline
\end{tabular}

Source: CSA (1994, 2000, 2007, http://en.wikipedia.org/wiki/List_of_woredas_in_the_Amhara_Region accessed on 20 January 2011);*Orthodox Christianity and Sun Muslim; **In Ethiopia, agro-ecologies are traditionally categorized into low land $(<1500 \mathrm{~m})$, intermediate $(1500-2000 \mathrm{~m})$ and highland $(>2000 \mathrm{~m})$ above sea level. Our study covered only the highland areas. 
Table 3 Reasons why farmers prefer barley and their importance

\begin{tabular}{ll}
\hline Reasons & Importance \\
\hline - Suitable for high altitude, performs better than other crops & Very important \\
- Tolerant to weather and agronomic stresses like frost, water logging, weeds, diseases, and insects & Very important \\
- Suitable for many kinds of dishes (including injera) with a better taste & Very important \\
- Good source of energy and consuming barley foods gives body strength & Very important \\
- Medicinal purposes for gastritis, headache and can heal broken bones and fractures & Very important \\
- The best choice for local beverages & Very important \\
- Relatively high yielding with low management & Very important \\
- Produces high quantity and quality straw for feed, which is preferred by animals & Important \\
- Quality straws for roofing (thatching) houses and bedding & Important \\
- Grain, flour and food products store better than other crops & Important \\
\hline
\end{tabular}

months), while the belg season is through January to July, with mid January to end of February/early March considered as the best belg planting time for late type landraces to harvest before the meher season rain starts. Otherwise, early maturing types can be planted as late as April and harvesting may go into July where there is a risk of damage by the main season rainfall. Belg barley producing areas, mainly S.Wello, are characterized by black soils which are prone to water logging. Consequently, flat plains or low laying areas are not workable during the main rain season. If planted on such plains, the performance of barley would be very poor. There is also a frost problem in September/October. Therefore, majority of the fields in these areas are left flooded during the main rainy season and land preparation is through September to December. This practice is noticeable in Gragn meda and Guguftu (Dessie zuria) and Gimba (Legambo), where fields are left fallow during the meher season, and covered with barley crop during the belg season. The implications of insufficient belg rainfall and subsequent crop failures are serious on food security of these areas. The situation is, however, different in N.Wello, where it is common, during the meher season, to see barley crop fields side by side with fallow fields left for belg barley planting (Figure 3). The belg season is less dependable except some areas with water logging and frost problem where farmers rely mainly on the belg barley production. In general, if farmers fail to plant during the belg season, they may still be able to plant barley during the meher season. This is not to imply that the belg barley system is not important in $N$. Wello but to indicate that belg crop failures will have more localized livelihood impacts compared to S.Wello.

\section{Ethnobotany and Types of landraces grown}

Farmers in the study districts purposely maintain landraces to address various needs. These needs included, but not limited to, suitability for early or late planting (i. e. maturity), yield potential in relation to the type of environment intended to be grown, conditions of the soils (i.e. water-logged, fertility or frost effects), and intended dishes and beverages (includes quantitative and qualitative aspects such as product volume, taste, visual appeal, color, storability etc). Fifteen landraces were grown, which vary in maturity, yield potential, stress tolerance, end-use qualities and other agronomic traits. Table 5 highlights the ethno-botany of some of the landraces grown by farmers, which gives some idea about the richness of landraces types and their management as described by the farmers. The naming and descriptions of the landraces reflect key quantitative, qualitative traits and end-use qualities as well as other information such as planting time or origins. The most common landraces listed by farmers were Nechita,

Table 4 Area coverage, production and rank of barley in the three administrative zones

\begin{tabular}{|c|c|c|c|c|c|c|}
\hline Administrative levels & area (,000 hectare) & $\%$ & production (,000 quintal) & $\%$ & rank & number of administrative units* \\
\hline Wag Hemra & 12.98 & 14.08 & 94.12 & 16.65 & $3^{\text {rd }}$ & 3 districts \\
\hline N.Wello & 33.95 & 14.61 & 292.34 & 12.87 & $3^{\text {rd }}$ & 8 districts \\
\hline S.Wello & 25.1 & 7.01 & 239.37 & 6.79 & $4^{\text {th }}$ & 15 districts \\
\hline Amhara Regional State & 287.87 & 8,3 & 2488.52 & 7.53 & $5^{\text {th }}$ & 10 zones \\
\hline Ethiopia & 874.0 & 9.25 & 9454.2 & 8.91 & $5^{\text {th }}$ & 9 Regional States \\
\hline
\end{tabular}

Source: CSA (2000); *includes districts, zones and regional states where barley may not be important. Barley is the third important crop in North Wello and Wag Hemra after tef and sorghum while it ranks $4^{\text {th }}$ in South Wello after tef, sorghum and wheat. At the regional state and national levels, barley ranks $5^{\text {th }}$ after tef, sorghum, maize and wheat. Oromiya, Amhara and Tigray Regional States account about $87 \%$ of barley production in the country. 


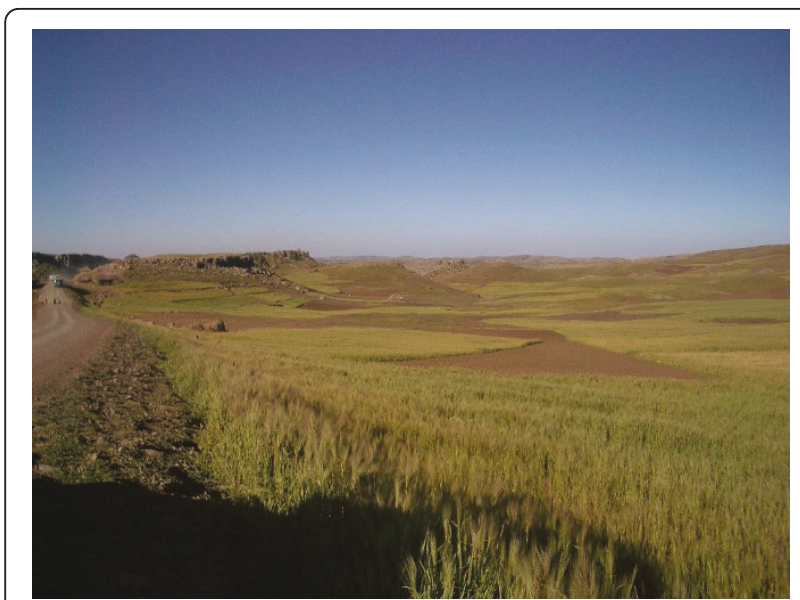

Figure 3 Meher season barley fields in October around Kebero meda locality (N.Wello) side by side with plots prepared for belg planting

Ginbote, Wongada, Sene gebs, Ehil zer, Enat gebs, Wogere, Meher gebs (Ere), Ahya Asin, Tikur gebs, Gendit, Agere, Tsebel, Zibna and Temej. Majority of these landraces are six row types. The landraces from Wag Hemra are early maturing and two rowed that are adaptable to low moisture and short growing meher season of the area.

All the landraces listed by farmers are hulled except Temej. The landraces may be planted as pure stand (the dominant system) or in mixtures. If planted in mixtures, usually one or two landraces dominate the mixture. Although frequently mentioned as an important landrace, Tikur gebs was observed grown in mixture with other landraces with hardly any pure stand indicating the preference for white seeded types which cover wider areas. The farmers also mix-plant barley, particularly in $N$.Wello, with wheat, and this practice is known as Wasera. The number of landraces mentioned was higher in N.Wello and S.Wello. In areas where both the belg and meher seasons plantings are practiced, majority of the landraces may be planted either in the belg or meher season depending on the onset of the rainfall. For example, the belg rain occasionally starts very early making it possible to plant late maturing types including the ones usually grown during the meher season. Landraces like Ehil zer are grown both in the belg and meher seasons. In fact, farmers may use the produce from meher as a seed source for belg planting, and vice versa.

\section{Barley Foods and their Preparation}

More than 20 types of traditional barley dishes and beverages were reportedly prepared from barley. The food and beverage products are prepared from ground/milled barley flour, whole/cracked grains, roasted or boiled grains for main, side, ceremonial and recuperating dishes.
Some of the dishes and beverages prepared from barley are shown (Figure 4). The food value of barley as sources of energy is highly acknowledged by the farmers. Some dishes are served to breast-feeding mothers with the belief that they enhance breast milk production. Besides, some dishes are claimed to be a remedy for gastritis, while some others are reported to be a good substitute for breast milk; good to heal broken bones and fractures. For foods prepared from flour, the milling of barley is done either by special stone mill (traditional hand-grind grains using a stone grinder) or motorised mill. The flour can be stored from 6 months to 10 years depending on the temperature of the area with high temperature storage places increasing the rate of deterioration. Containers made of clay (pots) or mud and/or animal skin (akimada) are used for storing flour. Some farmers in $S$. Wello reported that flours from traditional stone mills store better than from motorized mills. This could be related to more frictional heat with motorized mills leading to hotter milled flours. Nishita and Bean [19] have measured temperatures up to $75^{\circ} \mathrm{C}$ during milling of rice. Motorized milled are also expected to grind finer than manual mills, and the increase in surface area from finer particles possibly exposes barley components more to deterioration. Table 6 summarizes the different dishes and beverages prepared from barley. A more detailed description of the different dishes and traditional beverages prepared by the farmers of the study area is presented below along with their preparations.

\section{i) Barley Foods from raw-grain flour}

The main food products prepared from raw barley grain flour are injera, kita and dabo. Injera, an unleavened thin pan cake, is the main dish and daily diet of the people in the area served with sauces. Enat gebs, Sene gebs and Meher gebs are the preferred landraces. The grain is well dried, cleaned, dehulled using mortar and pestle, heated lightly and milled in to moderate fine flour, sieved and dough is prepared. The dough preparation and other procedures for making injera are well-documented [20], and they essentially tally with the reports from the farmers in the study area with some variations. For example, fermentation can be for 2-4 days, but, if time is limited, the dough can be fermented for only one or two days. The injera from well fermented dough makes a better sourer taste and has good storability. The higher is the altitude, the longer is the fermentation time required as temperature would be lower. Lactic acid bacteria and yeasts are the main fermentation organisms in injera [20], and their products coupled with a drop in $\mathrm{pH}$ would stabilize injera during storage. Besides, in some areas, particularly in S.Wello, small quantities of malt flour as well as erimito are added during dough making to improve the injera quality and storability. Erimito is prepared from coarsely ground 
Table 5 Vernacular names \& their meaning as well as descriptions of major barley landraces grown in North Eastern Ethiopia

\begin{tabular}{|c|c|c|c|c|c|c|}
\hline Names & Zones & Meaning & $\begin{array}{l}\text { No of } \\
\text { rows* }\end{array}$ & $\begin{array}{l}\text { Seed } \\
\text { colour }\end{array}$ & Maturity & $\begin{array}{l}\text { Preferred } \\
\text { use }^{* *}\end{array}$ \\
\hline Agere & $\begin{array}{l}\text { N. and } \\
\text { S.Wello }\end{array}$ & $\begin{array}{l}\text { The landrace has been cultivated in the area for long time and it is not } \\
\text { considered as introduction from somewhere else. }\end{array}$ & six & white & Medium & Injera \\
\hline $\begin{array}{l}\text { Ahya } \\
\text { Asin }\end{array}$ & N.Wello & Asin refers to the heaviness of the grain for donkey (Ahya) to carry & six & & Medium & Injera \\
\hline Ehil zer & N.Wello & $\begin{array}{l}\text { Ehil and zer mean crop and seed, respectively. The context of the naming implies } \\
\text { the earliness of the landrace to produce some seed irrespective of the growing } \\
\text { condition (moisture stress, poor soil, frost) }\end{array}$ & irregular & purplish & Early & Beverages \\
\hline $\begin{array}{l}\text { Enat } \\
\text { gebs }\end{array}$ & $\begin{array}{l}\text { N. and } \\
\text { S.Wello }\end{array}$ & Barley as good as mother (Enat), and best of all the landraces. & six & white & Late & $\begin{array}{l}\text { Injera, } \\
\text { beverages }\end{array}$ \\
\hline Gendit & N.Wello & The landrace has a very long spike (head). & six & white & Medium & $\begin{array}{l}\text { Injera, } \\
\text { beverages }\end{array}$ \\
\hline Ginbote & N.Wello & A landrace planted in May (Ginbot). & six & white & Late & $\begin{array}{l}\text { Injera, genfo, } \\
\text { kolo, kinche }\end{array}$ \\
\hline $\begin{array}{l}\text { Meher } \\
\text { gebs (Ere) }\end{array}$ & $\begin{array}{l}\text { N. and } \\
\text { S.Wello }\end{array}$ & Barley landrace grown during the meher season. & six & white & Medium & Injera \\
\hline Nechita & N.Wello & $\begin{array}{l}\text { The name refers to the whiteness of the seed. It has whiter seed than other } \\
\text { landraces. }\end{array}$ & $\operatorname{six}$ & $\begin{array}{l}\text { Bright } \\
\text { white }\end{array}$ & Medium & $\begin{array}{l}\text { Genfo, } \\
\text { kinche, kolo }\end{array}$ \\
\hline $\begin{array}{l}\text { Sene } \\
\text { gebs }\end{array}$ & $\begin{array}{l}\text { N. and } \\
\text { S.Wello }\end{array}$ & Barley planted in June (Sene). & irregular & white & Medium & Injera \\
\hline Temej & $\begin{array}{l}\text { N. and } \\
\text { S.Wello }\end{array}$ & Hull-less barley & six & white & Medium & Kolo \\
\hline $\begin{array}{l}\text { Tikur } \\
\text { gebs }\end{array}$ & $\begin{array}{l}\text { N. and } \\
\text { S.Wello }\end{array}$ & black (Tikur) color of the barley grain & $\begin{array}{l}\text { six, } \\
\text { irregular }\end{array}$ & Black & Medium & Beverages \\
\hline Tsebel & $\begin{array}{l}\text { Wag } \\
\text { Hemra }\end{array}$ & $\begin{array}{l}\text { Barley landrace that produces grain with very low rainfall, a rainfall as small as } \\
\text { holy water (tsebel). }\end{array}$ & two & white & Early & $\begin{array}{l}\text { Injera, } \\
\text { beverages }\end{array}$ \\
\hline Wogere & N.Wello & - & six & white & Medium & $\begin{array}{l}\text { Injera, } \\
\text { beverages }\end{array}$ \\
\hline Wongada & N.Wello & - & six & white & Medium & Injera \\
\hline Zibna & $\begin{array}{l}\text { Wag } \\
\text { Hemra }\end{array}$ & - & two & white & Early & $\begin{array}{l}\text { Injera, } \\
\text { beverages }\end{array}$ \\
\hline
\end{tabular}

* If the soil is fertile, irregular row type landraces like Ehil zer grow to have six rows; ${ }^{* *}$ preference depends on ability to grow the landrace per se. There is no landrace, except Temej, that cannot be used for injera which is the main dish of the study area. In other words, the less preferred ones are used for making injera if preferred ones are not available. For example, Ehil zer is widely used for making injera in $N$. Wello because it is the landrace that is relatively better adapted and stable yielding compared to other landraces (e.g. Enat gebs \& Ginbote).

barley flour by mixing with water to form thick dough, which is made into small balls and stored for couple of weeks. A good injera is soft, fluffy and spongy with good and well distributed 'eyes' and it does not break when rolled. Farmers stressed that the skills (moya) of women in getting the right balance in the fermentation and baking process affect the quality and storability of injera. Women usually put leaves, plastic or pulses grains on the mesob (injera storage made of woven grass) under the injera to improve its shelf-life. The injera is baked on clay pan, mitad (also known as mogogo in some areas). Wheat, tef, sorghum, and maize flour can be mixed with barley flour for making injera.

For making kita, the flour is mixed with water and kneaded by hand with a pinch of salt to make thick unfermented dough. Then, it is baked immediately on both sides using a clay pan (mitad) or iron pan (biret mitad) by turning after being baked on one side. Kita is a relatively thicker and harder bread but smaller in size (about the size and thickness of a pizza base) compared to injera. It is served either with butter, milk, or linseed paste. It is instant bread usually prepared for immediate consumption for children or as an emergency food when no injera or kolo is available. The term kita is used for any product prepared from unfermented dough with or without qualifying it. Dabo is leavened homemade bread, which is much thicker and softer than kita. The dough is prepared thick with salt added for an overnight fermentation. A leaven (ersho) is added as a starter of fermentation, which is also the case for injera. The ersho is usually obtained by saving a small amount of the previous injera dough. Dabo is baked on both sides by burning fire on both sides after covering the top with leaves/mud/clay. It is usually prepared for holidays or cultural gatherings. Although wheat is the preferred crop for dabo, barley is used where it is the only 


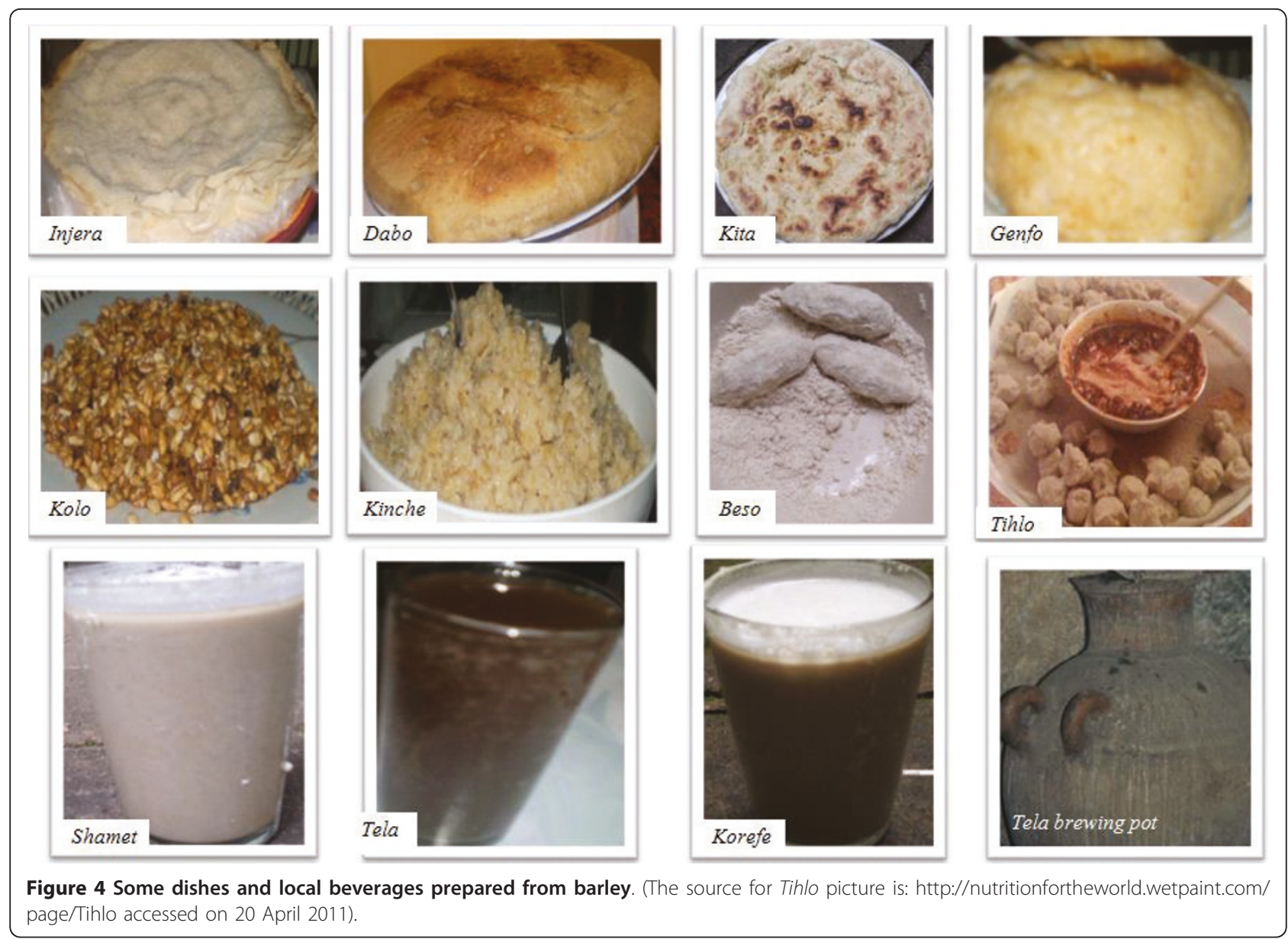

option in higher altitude areas. The flour for kita and dabo is taken from that prepared for injera.

\section{ii) Barley foods from roasted/boiled whole grain}

Various roasted and boiled barley foods are known to the study area, but kolo, a roasted grain, is the most widely consumed. To prepare kolo, the grain is dehulled using hot water directly or after soaking in water for few hours to facilitate dehulling. The dehulling is carried out mechanically by pounding the hot water treated or soaked grains using mortar and pestle. The grains are heated on the sun or on iron/clay pans to dry the hulls, which are subsequently blown prior to roasting. Then the grains are roasted and lightly pounded using mortar and pestle or hand rubbed to remove the remaining hulls followed by final blowing. Kolo is consumed sole or mixed with roasted field pea, faba bean, safflower or chickpea. It is usually consumed as a snack dish served before the main dish, and during coffee ceremony and other cultural occasions. Kolo is also a good travelling food as it stores well. Temej, Nechita and Ginbote are the preferred landraces for kolo.

The same dehulled whole grain barley for kolo can be boiled sole or mixed with pulse to make nifro to be served as a snack. Barley nifro is not as common as kolo with other crops such as wheat, and pulses being preferred. It is mainly prepared for cultural occasions. Another roasted whole grain food types are eshet and enkuto, which are consumed in the field before the crop is harvested. Barley spikes at dough stage (eshet) are consumed as raw green grains or flame roasted by children, or dry (matured) spikes are flame roasted (enkuto) and consumed. Another form of roasted barley uses includes barley tea and coffee. Whole grain barley is roasted dark colour and boiled to make barley tea, or mixed with roasted coffee and ground using mortar and pestle to make coffee. But, the use of barley as tea and coffee is very limited in the area.

\section{iii) Barley foods from roasted-grain flour}

At least five types of food products are prepared from roasted barley grain flour:genfo, muk, beso, shamia and tihlo with genfo (porridge) and beso being more commonly consumed. Barley grain for genfo is partially dehulled using mortar and pestle, and sun-dried or most often lightly roasted to, according to the farmers, increase "water uptake ("wuha endiyanesa") during cooking so that high volume genfo can be obtained from 
Table 6 A brief description of the types and preparation methods of barley dishes and beverages in North Eastern Ethiopia

\begin{tabular}{|c|c|c|}
\hline Name & Method of preparation/processing & Frequency of use \\
\hline Injera & $\begin{array}{l}\text { A leaven bread made from raw grain flour with the dough fermented for } \\
2-4 \text { days and baked on clay pan }\end{array}$ & - It is the main daily dish \\
\hline \multirow[t]{2}{*}{ Kita } & Instant bread baked from unfermented dough of raw grain flour & - Occasionally when no Injera or kolo is available. \\
\hline & & - Usually prepared for children \\
\hline \multirow[t]{2}{*}{ Dabo } & Thick bread baked from fermented dough of raw grain flour & - Not common \\
\hline & & - Wheat is preferred \\
\hline \multirow[t]{2}{*}{ Kolo } & Roasted grain prepared from dehulled barley & - Prepared daily as additional food to the main meal \\
\hline & & - Also used as travelling food \\
\hline \multirow[t]{2}{*}{ Nifro } & Boiled grain prepared from dehulled barley & - Prepared occasionally \\
\hline & & - Mostly prepared for cultural occasions \\
\hline \multirow[t]{3}{*}{ Beso } & Solid food prepared from roasted barley flour and water & - Prepared occasionally \\
\hline & & - Relieves gastritis \\
\hline & & - Used as travelling food \\
\hline \multirow[t]{3}{*}{ Shamet } & Semi fluid drink made from roasted barley flour & - Prepared occasionally by farmers \\
\hline & & - Daily for sale in towns \\
\hline & & - Relieves gastritis \\
\hline \multirow[t]{2}{*}{ Genfo } & Thick porridge prepared from raw or lightly roasted grain flour & $\begin{array}{l}\text { - Commonly as a substitute or when other dishes are not } \\
\text { prepared }\end{array}$ \\
\hline & & - Commonly prepared for postnatal mothers \\
\hline \multirow[t]{2}{*}{ Kinche } & $\begin{array}{l}\text { A dish prepared from cracked raw barley grains. Somewhat equivalent to } \\
\text { oat meal. }\end{array}$ & - Occasionally as a substitute to other dishes \\
\hline & & - Breakfast \\
\hline \multirow[t]{2}{*}{ Muk } & Gruel made from raw barley grain fine flour & - Occasionally for a change \\
\hline & & - Mostly prepared for children and sick person \\
\hline Shorba & Semi fluid drink prepared from cracked grain & Occasionally and commonly during Ramadan \\
\hline Tihlo & Prepared from roasted barley flour and water, served with sauce & - Occasionally and it is only known in Wag Hemra \\
\hline \multirow[t]{2}{*}{ Tela } & $\begin{array}{l}\text { Alcoholic beverage prepared from gesho, malt, roasted grain (derekot or } \\
\text { asharo) and kita }\end{array}$ & - Prepared mainly during holidays/traditional ceremonies \\
\hline & & - Commonly prepared and sold in towns \\
\hline \multirow[t]{2}{*}{ Bukre } & Non-alcoholic beverage prepared from malt, roasted grain and kita & - Prepared occasionally, usually for holidays \\
\hline & & - Prepared by Muslims \\
\hline \multirow[t]{2}{*}{ Korefe } & $\begin{array}{l}\text { Alcoholic beverage prepared from gesho, malt and lightly roasted barley } \\
\text { grain and kita }\end{array}$ & - Occasionally for holidays \\
\hline & & - Usually prepared and sold in towns \\
\hline \multirow[t]{2}{*}{$\begin{array}{l}\text { Filtered } \\
\text { tela }\end{array}$} & $\begin{array}{l}\text { An alcoholic beverage similar to tela with a slightly different preparation } \\
\text { and higher alcoholic content }\end{array}$ & - Occasionally during holidays \\
\hline & & - Sold in towns \\
\hline Eshet & Barley seeds consumed green at milky/dough stage & $\begin{array}{l}\text { - Consumed in the field during grain filling stage mainly by } \\
\text { children minding livestock. }\end{array}$ \\
\hline Enkuto & Flame roasted mature dry spikes consumed in the field & - Occasionally during harvest time \\
\hline Areke & Alcoholic spirit & - Occasionally and wheat is preferred \\
\hline $\begin{array}{l}\text { Teal } \\
\text { coffee }\end{array}$ & Drink from dark roasted barley & $\begin{array}{l}\text { - In very limited cases and when proper tea/coffee has run } \\
\text { out. }\end{array}$ \\
\hline
\end{tabular}

a small amount of flour". The high volume could be as a result of partial gelatinization of starch in the grain due to roasting. Gelatinized starch generally absorbs more water, and swells more than non-gelatinised starch [21]. The lightly roasted grain is milled and sieved to remove remaining hull. The flour is added with some salt in boiled water and cooked with occasional stirring. Genfo is served hot either in the pot or in a bowl with spiced butter, honey, berbere (spiced paprika/chilli) or linseed paste. The dish is usually prepared for post-natal women or for a sick family member. But, it is also prepared sometimes as a variety dish, as a substitute for a 
common dish as it takes less time to prepare. In general, genfo is preferred as a breakfast food.

The grains for beso may or may not be dehulled before milling. It is a common practice to roast the grains first and partially dehull with mortar and pestle before coarse milling and sieving followed by fine milling and subsequent sieving. Beso is prepared using cold or hot water to moisten the flour on a bowl in such a way that it can be balled/rolled using hand and served. Salt is usually added in the water, but sugar or melted spiced butter can also be added if available. According to the farmers, beso cures gastritis. It also helps to alleviate food shortages during September November because the matured grain, which is not very well dried yet and cannot be used for other dishes, can be harvested from field and threshed to be used for preparing beso. Tihlo is prepared in Wag Hemra zone. The processing of barley for tihlo is similar to beso but the grain is completely dehulled and the milling requires extra care to avoid mixing with flours from other crops which might decrease the quality. Also, more water is used to prepare tihlo than beso. Tihlo is usually balled by hand and served with freshly made hot shiro wot (sauce made from pulses flour and spices).

The flour for shamia (shamet) is the same with beso flour, but shamia is prepared as a drink. Beso flour is mixed with cold water plus sugar, and served in a cup or glass. Shamia is not prepared frequently, and it is considered as a luxurious food item as sugar might not be readily available. Farmers prepare shamia mostly when someone suffers from gastritis as it is considered medicinal. It is more commonly prepared in towns for sale. Beso flour is a preferred travelling food ("yemenged sink") as the dishes are easy to prepare, and the flour can be stored for long with no quality deterioration. Muk (gruel) is a very smooth semi-solid drink. The barley grain is dehulled and milled into fine flour and sieved. The flour is added to boiling water and cooked with occasional stirring. Once cooked, it is usually served hot with sugar. Muk is usually prepared for sick people and children, but it is also a favorite drink by women.

\section{iv) Barley foods from cracked grain}

Kinche and shorba are the two most important dishes prepared from cracked barley grains with Nechita and Ginbote as the preferred landraces. For kinche, the grain is dehulled using mortar and pestle, roasted very lightly, cracked into four or five parts, sieved and cooked in boiled water with occasional stirring to get a thick consistency. Sugar is added and kinche is served when it is cold, and spiced butter, if available, can also be added. It is considered as a luxury food and, therefore, prepared occasionally for changing diet and/or as an alternative dish when other dishes are not readily available. The preparation of barley for shorba (soup) is the same to that of kinche except that more water is added to shorba. Thus, it is a drink served hot in a cup or using spoon in a bowl. It can be mixed with some vegetables and pulses but it is usually served sole with sugar, salt and spiced butter (if available). It is a very important dish during Ramadan, when it might be prepared daily.

\section{v) Traditional Beverages}

Tela, filtered tela, korefe, bukre and areke are the various beverages locally prepared from barley. Tela (also known as zilil in some woredas) is the most common and preferred local beverage. It is usually prepared for annual and religious holidays, and traditional ceremonies, but also for sale in towns and cities. The ingredients for making tela are barley malt, gesho (Rhamnus prinoides), derekot (or asharo), kita (qualified as tela kita) and water. The brewing clay pot ( $\mathrm{gan})$ is washed several times and smoked with locally available selected shrubs to properly clean it. Barley malt flour and dried gesho leaves (ground by mortar and pestle using water), are mixed with water in the gan and left for 2-5 days to ferment and yield. This is called tinsis. The purpose of gesho seems to be similar to hops in commercial brewery as it has a bitter taste and adds a bitter flavor to tela by balancing the sweetness of the malt. The kita is prepared by lightly roasting barley and milling before a non-fermented dough is prepared and baked. The kita and pounded gesho stems are added to the tinsis and allowed to ferment overnight. Simultaneously, another barley grains are boiled, dried and roasted black to make derekot, which is then milled to flour and added, in equal amounts to kita, to make difdif. When the difdif is fermented well for 3-4 days, enough water is added and the pot is sealed to make tela, which is usually left for 5-7 days to make purified and clarified quality tela. When the clarified tela is used, fresh water could be added and left overnight to ferment to get secondary and weaker tela called kirare. The leftover (byproduct) after the kirare, called atela, is commonly fed to animals. The derekot can be substituted by asharo, which is prepared simply by roasting black the barley grain without boiling. Tela from derekot is preferred. But since it is tedious and takes long time to prepare the derekot (boiling, drying, roasting etc), its use is limited, and asharo is commonly used to prepare tela. Derekot is usually used when a big cultural ceremony is planned like wedding where the hosts would brew a quality tela.

In N.Wello, women keep part of the difdif (made from derekot, not asharo) in a separate clay container for up to three or more months, from which quantities are taken to prepare tela. The name, zilil, for the tela implies the practice of saving part of the difdif. A small quantity of the difdif is taken to a brewing pot and 
more water added to make the tela that would be ready to use after overnight fermentation. Filtered tela is made in the same way as tela, but more concentrated with higher alcohol content due to less water added, and filtered through a cotton cloth (this makes it clearer than tela) and kept in a sealed container. It can be kept for a longer period of time, upto three weeks. Korefe, another form of tela, is prepared mainly in N.Wello and Wag Hemra zones. The preparation is similar to zilil in that the difdif is kept for a long time, and a part is used to make tela that ferments overnight. But the difdif is filtered in a pot using clean cotton cloth by adding water similar to filtered tela. If it is filtered in the afternoon, it would be ready to serve in the morning of the next day. While the other forms of tela are brown, korefe is lighter in color because the asharo is not roasted very dark. Normally, korefe is not purified and clear when served and it has white bubbles (korefe).

Bukre is another beverage mainly prepared by Muslims, and its preparation is similar to tela except that gesho is not added. Bukre is considered as alcohol free drink although the preparation follows a lot of fermentation process. Areke is a distilled spirit with preparation and fermentation process similar to tela. Instead of adding more water to make clear tela, the fermented product (difdif) is boiled in a sealed clay pot and the steam is distilled. Barley is not the first choice as other crops are preferred for quality areke.

\section{Discussion}

\section{Importance of barley}

For the subsistence farmers of North Eastern Ethiopia highlands, barley is the crop of choice for many reasons (Table 3). Although some of these reasons have been proven scientifically (e.g. tolerance to frost and storage stability) [22,23], many other reasons could initiate scientific investigations. Some of the areas are above tree border line (adaptation zone) where no trees or shrubs are observed (e.g. Figure 3). Only barley can be planted in these areas. By the farmers' estimates, about $90 \%$ of the produce is used for home consumption, of which about $10 \%$ is for local beverages while the rest is for food. This figure is higher than 40\% [7] and 79\% [24] quoted earlier for national consumption of barleybased foods in Ethiopia. This could be attributed to the subsistence nature of the farming and also to the study area being drought prone limiting food security of farmers. Out of the 105 woredas in the Amhara Regional State, 48 woredas are drought-prone and food-deficit [25]. All the woredas in our study fall in this category.

Farmers grow many landraces, which vary in maturity, yield potential, stress tolerance, end-use quality, and other agronomic traits. The landraces are purposely maintained to address various needs. Similar reasons were noted why farmers kept many landraces of barley in central Ethiopia [15], potato in the Andes [26], rice in China [27], various crops in Italy [28], sorghum in $S$. Wello, Ethiopia [29], maize in Mexico [30], and durum wheat in East Shewa, Ethiopia [13]. The different landraces planted in the study areas were identified, named and described by the farmers. Studies on other crops showed that vernacular names and farmers' descriptions of landraces can relate to formal scientific classifications. For example, in S.Wello, Teshome et al. [6] found that the sorghum landraces named by farmers could be discriminated very well as distinct types on the basis of formal taxonomic classification using morphological characters. We did not attempt to characterize the phenotypic (quantitative or qualitative) traits of each landrace grown by the farmers.

\section{Diverse use of barley for dishes and beverages}

According to the farmers, there is no other crop they know or are aware of that is as suitable as barley to prepare many of the dishes and beverages known in the study areas. The expression "barley is the king of crops ("gebs ye ehil nigus")" emphasizes its suitability for diverse use. More than 20 types of traditional barley foods and beverages were described by farmers. Some of these dishes and beverages like beso, shamia, tihlo, korefe and genfo are exclusively prepared from barley. Some dishes and beverages may be prepared from other crops. For example, tela and bukre may be prepared from sorghum or maize, and kolo can be prepared from wheat or pulses, but the quality and taste would not be as good as that from barley. As it was reported for farmers in central Ethiopia [15], the various barley foods and drinks also play an important role in the socio-economic and cultural life of farmers and urban dwellers of the study area. Special events like wedding, annual festivals and ceremonies are celebrated with foods and drinks of barley. Traditionally, it is a custom in many parts of Ethiopia (both rural and urban areas) to prepare barley flour for genfo for an expectant mother and barley is the crop of choice. A postnatal mother eats genfo with spiced butter for breakfast and her guests are also served genfo. Neighbours and close relatives usually prepare barley genfo and take to the new mother. Besides, tela is sold in small towns and cities as a source of income for many families.

Although, there could be differences in the method of preparation/processing, preference for certain crop types (e.g. tef, wheat, maize or barley), types of crop varieties (landraces, improved) and naming of dishes (due to language differences), many of the dishes and beverages reported to be prepared in the study areas are also widely prepared in other parts of the country. For example, injera is the stable diet of majority Ethiopians; tela 
and kolo are also widely consumed. Studies on barley in central Ethiopia $[14,15]$ listed many of the dishes and beverages described by farmers in the study area. However, some of the dishes and beverages like korefe, zilil and tihlo seem to be specific to this part of the country. On the other hand, borde (a beverage), kori (a roasted grain coated with spiced butter) and chiko (a solid food made from beso flour and ghee) described by [15] were not familiar in the study area. Besides, the barley landraces cultivated in central Ethiopia [15] were entirely different (at least in name if not genetically) from the ones in our study areas. Generally, the skills and methods of preparation/processing of the different dishes and beverages are likely to be affected, among others, by the types of crops grown in a particular area. In the lower and intermediate areas where barley is not the dominant crop, injera is mainly prepared either from tef, sorghum, maize or wheat. In towns and cities, tef is usually the preferred crop for making injera. Injera from sorghum or maize would probably have a relatively different processing method. Even for the same crop, adding erimito and malt in the dough making process for injera from barley seem unique practices to the study area. But the overall approach of preparing injera such as the need for fermentation, use of starter and baking essentially remain similar across the country $[15,20]$.

\section{Health benefits of barley dishes}

In addition to the food values, the farmers often emphasised the medicinal properties and health benefits of the different dishes prepared from barley. For example, shamia is believed to be a remedy for gastritis; muk can serve as a substitute for mother's milk for children. $M u k$, genfo, kinche and other barley foods are believed to heal broken bones and damaged body parts. Besides, these dishes are considered smooth and easily digestible to serve to sick person who cannot take another form of food for quick recovery. The tradition of preparing genfo for postnatal mothers is related to the benefit of barley for quick recovery from the effect of child birth. The farmers also mentioned that barley is often fed to broken or rested ox, a valuable asset for ploughing the land, for quick recovery. Some of the health benefit claims about barley foods by the farmers are believed to have scientific basis, which is well documented [31-37]. Barley contains $\beta$-glucan soluble fibre and antioxidants, vitamins, minerals, and phytonutrients such as phenolics and lignans, which can reduce the risk of coronary heart disease, cholesterol absorption, diabetes and certain cancers. Such health benefits have created a renewed interest in barley for food. For example, the USA Food and Drug Administration has issued a health benefit endorsement for barley based on $\beta$-glucan effects on lowering blood cholesterol and reducing the risk of heart disease [38].
The development of a wide range of barley types allows for targeting barley cultivars to specific end uses [7]. There has been a focus on the development of improved hull-less barley with low or zero amylose (waxy), and high amylose content. Waxy cultivars typically have higher viscous soluble fibre, $\beta$-glucan levels than non-waxy types. Hull-less cultivars also permit greater ease in milling and pearling with enhanced processing yields [32,39-41]. The hull-less type of Ethiopian barley constitutes the genetic pool from which the lysine-high protein, hiproly barley was recovered by screening $[7,42]$. Throughout Ethiopia, the frequency of hull-less barley is low [7]. In North Eastern Ethiopia, hull-less barley is only used for kolo, and it is not preferred for other dishes. Besides, it is low yielding and it is only grown on small plots around homestead or mixed with other landraces.

\section{Relationship between end-use qualities and diversity of landraces}

Crop selection and maintenance decisions are generally made based on a set of criteria that has resulted in a complex and continually evolving collection of landraces. The selection criteria often reflect adaptations to changing farming conditions, and responses to the socio-economic and cultural factors that shape farmers priorities [15,26-30]. Diversity in end-uses is one of the important factors that influence the maintenance and genetic diversity of a particular crop. As highlighted in the previous sections, barley is put for diversity of uses in North Eastern Ethiopia, and the livelihood of highland farmers depends on barley. Not all landraces are equally suitable to make the various barley dishes and beverages prepared in the area. Different landraces are preferred for specific end-use. For example, Nechita is the best landrace for genfo, shorba, kinche; Tikur gebs for beverage; Temej for kolo; whereas Enat gebs, Sene gebs and Meher gebs are preferred for injera. These preferences are related to taste, color, visual appeal, water absorption (volume of product) and storability. According to farmers, Nechita is whiter than most landraces, and its food products have visual appeal and appetizing. It has good water absorption capacity, which gives a higher volume of product (e.g. genfo and kinche). Similarly, the suitability of landraces like Enat gebs and Meher gebs for their injera making quality is related to their water absorption capacity, fermentation process, baking quality, taste and storability of the resulting injera. The farmers consider the injera from these landraces as tasty and filling, soft, fluffy, spongy with good and well distributed 'eyes'. It stores longer and does not dry quickly or develop mold. The injera is usually consumed within four days but it could last upto seven days. Temej is the choice for kolo. It is hulless and easy 
to process as it does not require the tedious dehulling process using mortar and pestle, and winnowing before roasting. The roasted grain is tasty and easy to chew. Thus, farmers make all possible efforts to maintain various landraces suitable for specific end-use qualities by planting a landrace in mixtures with other landraces or allotting specific plots of land. It is common to observe mixed (intercropped) planting of many different types in the same field for various other reasons but mainly as buffer for risk aversions. The farmers also reported that mixing improves competition of landraces resulting in a better yield compared with pure stand of either. This may be attributed to the reduction of pests and disease damage, and compensation effects that result from between-plant differences and competition [43]. The practices of mixed planting and maintaining landraces on the basis of distinct functional attributes provide a chance for a low yielding type co-existing with high yielding types, which in turn maintain genetic diversity $[7,29]$. For example, despite being low yielding, Temej is maintained by farmers for its suitability for kolo. It is worth noting that preference is dictated by the availability of choice, which in turn is affected by a number of factors including rainfall, soil fertility, plot area and other environmental constraints.

\section{Genetic erosion}

Maintenance of various landraces is driven not only by end-use qualities but also by the rainfall condition of the season, soil type and fertility, maturity, frost tolerance, yield and other factors. Consequently, although farmers' practices enabled on-farm conservation of many landraces, some high-yielding late types like Enat gebs and Ginbote, which are mainly planted in May or early June, are being selected against because of moisture stress and soil degradation. These landraces are high yielding and are preferred by farmers for many end-use qualities but they require fertile soils and good moisture. The farmers also claimed that the produce and food products from late type landraces last long ("bereket alew"). The fertility of the soil is poor and natural resource degradation is the main problem in North Eastern Ethiopia [44-47]. The rainfall is also less reliable and recent climate change data indicated a late start and early cessation of the rainfall for meher season [48]. The lack of moisture in May to plant Ginbote and Enat gebs has shifted the preference to relatively earlier types like Sene gebs and Ehil zer. In Wag Hemra zone with a short meher season, farmers have very limited choice other than growing Tsebel and Zibna, which are early maturing landraces. Similarly, farmers plant early maturing types if the belg rain starts late. Generally, farmers are turning more on growing early maturing types that produce low but relatively stable yield. Hence, some of the preferred landraces are being or likely to be marginalized or pushed out of the production system, and this might lead to genetic erosion. Consequently, quality dishes and beverages prepared from the preferred landraces will be compromised with less suitable ones.

It was also reported that the household land holding for barley production has become smaller over the years to produce enough grain due to land fragmentation resulting from population pressure. Consequently, farmers are cutting on some less important ("luxury") dishes and beverages. For example, tela is not prepared as frequent as it used to be in 20-30 years time. Hence, landraces suitable for such types of products will ultimately become less important in the maintenance and management of diverse landraces. It may be worth mentioning that no improved barley varieties were grown by the farmers during the study. Thus, improved varieties are not a threat for the loss of landraces. IBC has been implementing on-farm conservation and enhancement of landraces for sorghum in S. Wello [49]. The goal is encouraging farmers to continue in maintaining landraces, which enables landraces to evolve for various traits in their area of adaptation. Encouraging results have been achieved with 111 landraces planted as mixtures in farmers' field every year in Kalu district [49]. Similarly, such on-farm conservation and enhancement may be relevant for barley landraces conservation in the study area. But the approach requires a sustainable system that benefits participating farmers to guarantee the continuity of the system and provides viable conservation outcomes. On-farm conservation efforts need to be linked to their use to ensure the long survival of crop landraces [13].

\section{Summary and Conclusions}

Barley, as a food and feed grain, is important to the livelihood of farmers in North Eastern Ethiopia. Information on the maintenance of barley landraces and their utilization for food is valuable to design and plan landraces conservation strategies as well as to improve food utilization of barley. The study has shown various reasons for the maintenance of diverse landraces as well as their different food uses, while highlighting the possible erosion of some preferred (culinary qualities) landraces. Incidentally in Ethiopia, most of the food barley varieties released nationally for wide adaptation and those released at state or zone levels for specific adaptation are developed based on yield performance. In the light of this, there is a need to incorporate grain quality as an added objective in barley breeding programs, as well as preserving and improving late maturing landraces.

On suitability for foods and beverages, there is a need for research on the barley quality traits required for the different dishes under different processing 
conditions including why some landraces are suitable for a specific food product. Some area-specific variations were observed in the way barley foods and beverages were processed. The effects of processing variations on the nutritive content of the barley foods and beverages have not been investigated, and how they par with processing methods in other barley growing areas is not known. The main limitation consistently mentioned by the farmers interviewed in the study with regards to food preparation from barley was that the manual processing of the grain (i.e. dehulling, grinding, sieving, roasting) is very tiresome and time consuming. The manual processing and removal of the hull have also an acknowledged wastage of some grains and it is also likely to have a negative effect on the nutritive value. It is important to investigate how to adapt for Ethiopia the various studies conducted elsewhere on barley as a food with a view to mechanizing many labour-intensive manual operations with simple utensils to maximize the benefits of barley as a food. Moreover, various spices and sauces are used with the different barley dishes. Although these ingredients or additives are known to improve taste, no information is available on their effects on the nutritive values of each dish. There are many nutritional and health benefits of barley, and exploring these for the various Ethiopian traditional foods and beverages could contribute to food security of the country.

\section{Abbreviations}

CSA: Central Statistics Authority, Ethiopia; IBC: Institute of Biodiversity Conservation, Ethiopia.

\section{Acknowledgements \\ The financial cost of the study was covered by Sirinka Agricultural Research Center. The technical assistance of Besufekad Tadesse, Rahel Asrat and Assefa Alebachew in the field survey is acknowledged. We are thankful to the farmers' who shared their knowledge and provided us with the information on ethnobotany, use of barley and maintenance of landraces. We are also grateful to the development agents and subject matter specialists of respective woreda agricultural offices and kebele administrative officials for facilitating role to meet farmers. The contributions of the anonymous reviewers are gratefully acknowledged.}

\section{Author details}

${ }^{1}$ Sirinka Agricultural Research Center, P.O.Box 74, Woldia, Ethiopia. ${ }^{2}$ School of Agriculture and Food Sciences, The University of Queensland, QLD 4072. Australia. ${ }^{3}$ Centre for Nutrition and Food Sciences, The University of Queensland, St Lucia, QLD 4072, Australia.

\section{Authors' contributions}

HS carried out the field study and wrote the manuscript. PS was involved in revising the manuscript critically for important intellectual content for it to have the present form. All authors read and approved the final manuscript.

\section{Competing interests}

The authors declare that they have no competing interests.

Received: 2 December 2010 Accepted: 28 June 2011 Published: 28 June 2011
References

1. CSA: Agricultural sample survey 2000/2001 (1993 E.C.) (September2000February 2001), Volume 1 Report on Area and Production of Crops (Private Peasant Holdings, Meher Season). In Statistical Bulletin. Volume 245. Addis Ababa: Central Statistical Agency; 2000.

2. Vavilov Nl: The origin, variation, immunity and breeding of cultivated plants. Chronica Botanica 1951, 13:1-366.

3. Qualset CO: Sampling germplasm in a centre of diversity: An example of disease resistance in Ethiopian barley. In Crop Genetic Resources for Today and Tomorrow. Edited by: Frankel OH, Hawkes JG. Cambridge: Cambridge University Press; 1975:81-96, EBP 2.

4. Bonman JM, Bockelman HE, Jackson LF, Steffenson BJ: Disease and Insect Resistance in Cultivated Barley Accessions from the USDA National Small Grains Collection. Crop Science 2005, 45:1271-1280.

5. Lakew B, Semeane Y, Alemayehu F, Gebre H, Grando S, van Leur JAG, Ceccarelli S: Exploiting the diversity of barley landraces in Ethiopia. Genetic Resources and Crop Evolution 1997, 44:109-116.

6. Teshome A, Baum BR, Fahrig L, Torrance JK, Arnason JT, Lambert JD: Sorghum [Sorghum bicolor (L.) Moench] landrace variation and classification in North Shewa and South Welo, Ethiopia. Euphytica 1997, 97:255-263.

7. Asfaw Z: The barleys of Ethiopia. In Genes in the Field: On-farm Conservation of Crop Diversity. Edited by: Brush SB. Boca Raton: Lewis Publishers; 2000:77-107

8. Hoisington D, Khairallah M, Reeves T, Ribaut J-M, Skovmand B, Taba S, Warburton M: Plant Genetic Resources: What Can They Contribute Toward Increased Crop Productivity? Proc Natl Acad Sci USA 1999, 96:5937-5943.

9. Toledo A, Burlingame B: Biodiversity and nutrition: A common path toward global food security and sustainable development. Journal of Food Composition and Analysis 2006, 19:477-483.

10. Ceccarelli S, Grando S: Barley landraces from the Fertile Crescent: a lesson for plant breeders. In Genes in the Field: On-farm Conservation of Crop Diversity. Edited by: Brush SB. Boca Raton: Lewis Publishers; 2000:51-76.

11. Jarvis $D$, Hodgkin $T$ : Farmer decision making and genetic diversity: linking multidisciplinary research to implementation on-farm. In Genes in the Field: On-Farm Conservation of Crop Diversity. Edited by: Brush SB. Lewis Publishers, Boca Raton, FL, USA; 2000:261-278.

12. Ranjil DK: Role of food tradition in conserving crop landraces on-farm. The Journal of Agriculture and Environment 2010, 11:107-119.

13. Tsegaye B, Berg T: Utilization of durum wheat landraces in East Shewa, central Ethiopia: are home uses an incentive for on-farm conservation? Agriculture and Human Values 2007, 24:219-230.

14. Bekele B, Alemayehu F, Lakew B: Food Barley in Ethiopia. In Food Barley: Importance, Uses, and Local Knowledge. Edited by: Grando S, Macpherson HG. ICARDA, Aleppo, Syria; 2005:53-82

15. Eticha F, Berghofer E, Grausgruber H: Utilization of barley (Hordeum vulgare L.) landraces in the highlands of West Shewa, Ethiopia. Plant Genetic Resources: Characterization and Utilization 2008, 7(2):154-162.

16. Eticha F, Sinebo W, Grausgruber H: On-farm Diversity and Characterization of Barley (Hordeum vulgare L.) Landraces in the Highlands of West Shewa, Ethiopia. Ethnobotany Research \& Applications 2010, 8:25-34.

17. CSA: Census 2007 Tables: Amhara Region, Tables 2.1, 2.4, 2.5, 3.1, 3.2 and 3.4 2011

18. CSA 1994 Population and Housing Census of Ethiopia: Results for Amhara Region 2011, 1(part 1)

19. Nishita KD, Bean MM: Grinding methods: Their impact on rice flour properties. Cereal Chem 1982, 59:46-49.

20. Yetneberk S, de Kock HL, Rooney LW, Taylor JRN: Effects of Sorghum Cultivar on Injera Quality. Cereal Chem 2004, 81(3):314-321.

21. Subrahmanyam SN, Hoseney RC: Shear Thinning Properties of Sorghum Starch. Cereal Chem 1995, 72(I):7-10

22. Reinheimer $\mathrm{J}$, Barr AR, Eglinton JK: QTL mapping of chromosomal regions conferring reproductive frost tolerance in barley (Hordeum vulgare L.). Theor App/ Genet 2004, 109:1267-1274.

23. G'orny AG: Variation in utilization efficiency and tolerance to reduced water and nitrogen supply among wild and cultivated barleys. Eupytica 2001, 117:59-66

24. Newman CW, Newman RK: A brief history of barley foods. Cereal Foods World 2006, 51:4-7. 
25. Bewket W: Rainfall variability and crop production in Ethiopia: Case study in the Amhara region. In Proceedings of the 16th International Conference of Ethiopian Studies. Edited by: Svein Ege, Harald Aspen, Birhanu Teferra and Shiferaw Bekele. Trondheim; 2009:823-836.

26. De Haan S: Potato diversity at height: Multiple dimensions of farmerdriven in-situ conservation in the Andes. PhD thesis, Wageningen University, The Netherlands; 2009 .

27. Gao L-Z: The conservation of Chinese rice biodiversity: genetic erosion, ethnobotany and prospects. Genetic Resources and Crop Evolution 2003, 50:17-32.

28. Negri V: Landraces in central Italy: where and why they are conserved and perspectives for their on-farm conservation. Genetic Resources and Crop Evolution 2003, 50:871-885.

29. Seboka B, van Hintum T: The dynamics of on-farm management of sorghum in Ethiopia: Implication for the conservation and improvement of plant genetic resources. Genetic Resources and Crop Evolution 2006, 53(7):1385-1403

30. Chambers KJ, Momsen JH: From the kitchen and the field: gender and maize diversity in the Bajio region of Mexico. Singapore Journal of Tropical Geography 2007, 28:39-56.

31. Ames NP, Rhymer CR: Issues Surrounding Health Claims for Barley. I Nutr 2008, 138:1237S-1243S.

32. Bird AR, Vuaran MS, King RA, Noakes M, Keogh J, Morell MK, Topping DL: Wholegrain foods made from a novel high-amylose barley variety (Himalaya 292) improve indices of bowel health in human subjects. British Journal of Nutrition 2008, 99:1032-1040.

33. Panfili G, Fratianni A, Di Criscio T, Marconi E: Tocol and $\beta$-glucan levels in barley varieties and in pearling by-products. Food Chemistry 2008, 107:84-91.

34. Keenan JM, Goulson M, Shamliyan T, Knutson N, Kolberg L, Curry L: The effects of concentrated barley $\beta$-glucan on blood lipids in a population of hypercholesterolaemic men and women. British Journal of Nutrition 2007, 97:1162-1168.

35. Behall KM, Scholfield DJ, Hallfrisch J: Diets containing barley significantly reduce lipids in mildly hypercholesterolemic men and women. American Journal of Clinical Nutrition 2004, 80:1185-1193.

36. Hallfrisch J, Scholfield DJ, Behall KM: Blood pressure reduced by whole grain diet containing barley or whole wheat and brown rice in moderately hypercholesterolemic men. Nutrition Research 2003, 23:1631-1642.

37. Bhatty RS: Milling yield and flour quality of hulless barley. Cereal Foods World 1987, 32:268-272.

38. Food and Drug Administration (FDA): Food Labelling: Health Claims; Soluble Fiber From Certain Foods and Risk of Coronary Heart Disease. Federal Register 2008, 73(37):9938-9947.

39. Škrbić B, Milovac S, Dodig D, Filipčev B: Effects of hull-less barley flour and flakes on bread nutritional composition and sensory properties. Food Chemistry 2009, 115:982-988.

40. Knutsen SH, Holtekjølen AK: Preparation and analysis of dietary fibre constituents in whole grain from hulled and hull-less barley. Food Chemistry 2007, 102:707-715.

41. Ames NP, Rhymer CR, Rossnagel B, Therrien M, Ryland D, Dua S, Ross K: Utilization of diverse hulless barley properties to maximize food product quality. Cereal Foods World 2006, 41:23-28.

42. Munck L: The case of high-lysine barley breeding. In Barley: Genetics, Biochemistry, Molecular Biology, Biotechnology. Edited by: Shewry PR. CABI, Wallingford, UK; 1992:573-601.

43. Zhang F, Li L: Using competitive and facilitative interactions in intercropping systems enhances crop productivity and nutrient-use efficiency. Plant and Soil 2003, 248:305-312.

44. Alemu G, Bayu W: Effects of farmyard manure and combined $\mathrm{N}$ and $\mathrm{P}$ fertilizer on sorghum and soil characteristics in northeastern Ethiopia. Journal of Sustainable Agriculture 2005, 26(2):23-41.

45. Hurni H: Degradation and conservation of soil resources in the Ethiopian highlands. Mountain Research and Development 1988, 8:123-130.

46. Taddese G: Land Degradation: A Challenge to Ethiopia. Environmental Management 2001, 27(6):815-824.

47. Tekle K: Land Degradation Problems and Their implications for Food Shortage in South Wello, Ethiopia. Environmental Management 1999, 23(4):419-427.
48. Segele ZT, Lamb PJ: Characterization and variability of Kiremt rainy season over Ethiopia. Meteorol Atmos Phys 2005, 89:153-180.

49. Mulat $G$, Yohannes T: South Wello in situ Crop conservation report for 1999/2000. In A Dynamic Farmer-Based Approach to the Conservation of Ethiopia's Plant Genetic Resources. Edited by: Tanto T, Demissie A. IBCR, Addis Ababa, Ethiopia; 2001:28-35, Progress Report 1999/2000.

50. Nyssen J, Simegn G, Taha N: An upland farming system under transformation: Proximate causes of land use change in Bela-Welleh catchment (Wag, Northern Ethiopian Highlands). Soil and Tillage Research 2009, 103(2):231-238.

doi:10.1186/1746-4269-7-19

Cite this article as: Shewayrga and Sopade: Ethnobotany, diverse food uses, claimed health benefits and implications on conservation of barley landraces in North Eastern Ethiopia highlands. Journal of Ethnobiology and Ethnomedicine 2011 7:19.

\section{Submit your next manuscript to BioMed Central and take full advantage of:}

- Convenient online submission

- Thorough peer review

- No space constraints or color figure charges

- Immediate publication on acceptance

- Inclusion in PubMed, CAS, Scopus and Google Scholar

- Research which is freely available for redistribution

Submit your manuscript at www.biomedcentral.com/submit
Ciomed Central 